\title{
DEVELOPING A SEPARATION ROSELLE SEPALS MACHINE
}

\author{
Atef A. Eliw*
}

ABSTRACT

A Separator Roselle (calyx) sepals machine was developed and fabricated in a local shop. The experiments have been carried out at El-Kasassin Horticulture Research station during harvesting season 2011. The studied parameters were; three cutting sepals pipe speed, different span times between harvesting and separation process (directly after harvesting, second day and third day), wood feeding disc with different orifice dimensions. The studied parameters were done at three replicates. The developed machine consists of eighteen separation units fixed in a metal frame, and operated by electric motor $1 \mathrm{hp}(0.75 \mathrm{k})$.The evaluation performance included machine productivity, separation efficiency, energy consumption, sepals damage, and economical costs, the developed machine was evaluated comparing to traditional method.

The obtained data showed that, the highest values of machine productivity of $18.522 \mathrm{~kg} / \mathrm{h}$, lowest sepals damage $1.66 \%$, separation efficiency of $98.36 \%$ and lowest specific energy consumption of 0.045 $\mathrm{kW} . \mathrm{h} / \mathrm{kg}$ were recorded in the case of cutting sepals pipe speed $100 \mathrm{rpm}$ , using feeding disk with 21/25 mm oriffice dimension and separation sepals after fruits harvesting directly. The total operation cost of 1.10 L.E/kg and 1.36 L.E/kg were obtained in mechanical and manual separation sepals respectively, but the net crop value from final product of sepals is much more expensive in mechanical method comparing to traditional manual method.

Key words: Roselle. Sepal separation, Operation condition, Performance evaluation. Separation cost.

* Senior Research, Agric. Eng. Res. Institute, Agric. Res. Center, Dokki, Egypt. 


\section{INTRODUCTION}

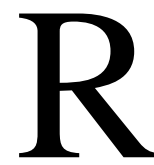

oselle (Hibiscus sabdariffa L) family Malvaceae, known commonly as "karkade" is cultivated in the tropical and subtropical countries. It is considered as one of the important medicinal plants. The main edible part is the fleshy sepal, called a calyx, surrounding the seed boll in the flower.

Egypt is the oldest country use the Karkadi (Hibiscus Sabdariffa L.) dried calyxes as tea. It is main planted in the upper Egypt. The dry sepals productions are 4871 ton from 8664 fed. at 2005 season (Ministry of agricultural, 2008).

More than 300 species of hibiscus are distributed in tropical and subtropical regions (Duke, 1978). Naturland and Kleinhaderner (2000) informed that the main producers of hibiscus blossoms are Egypt, Sudan, Mexico, Thailand and China. While the organic hibiscus cultivation is also currently practiced in Egypt, Tanzania, Mexico and Bolivia. The red calyces of the plant are increasingly exported to America and Europe. The production of hibiscus calyces in developing countries becomes important for income generation activities for the benefit of its countries. Communities the drug can also be used in cases of bacterial infections as it kills various micro-organisms (Sharaf, 1962). Roselle calyces contain two types of

Anthocyanins; hibiscin and gossiping that used in conjunction with a natural base for coloring syrups and liquors. The anthocyanins pigments of Hibiscus sabdariffa L., flowers are suitable for use as natural food coloring agents. The flower buds of $\mathbf{H}$. sabdariffa are used in refreshing infusion, decrease blood pressure, and cause relaxation of rat uteri, inhibition of Tania mortality and bacterial growth (Muller and Franz, 1992). Roselle is cultivated in Egypt throughout the country from north to south, although the southern regions are more suitable for its cultivation. However, the new reclaimed soils are suitable for such plants, which are able to grow under different climatic conditions. (Diatta and James, 2007).

Most hibiscus species are used as ornamental plants, but many are believed to have certain medicinal properties; among fruit tea or mixed with other herbal teas.

Naturland and Kleinhaderner (2000) informed that the fruit is separated with the calyx petals manually, either by hand, or with a knife. 
Afterwards, the seed capsules need to be carefully removed from the calyxes. Round, sharpened metal tubes can be used for this, to cut away the seed capsules at the base, and remove them. The seed yields about 20 $\%$ edible oil, and the residue produced after extract the oil is uses as a good feedstuff.

Badr et al. (2005) study the engineering factors which affect on Karkadi fruits threshing, the optimum threshing parameters were thresher drum speed of $4.03 \mathrm{~m} / \mathrm{s}$, clearance between the thresher drums of $6 \mathrm{~mm}$ and seed moisture content of $20 \% \mathrm{wb}$ to obtain the suitable seed damage of about $8.4 \%$, losses of about $2.6 \%$, clean efficiency of about $87.0 \%$, threshing efficiency of about $92.5 \%$, machine productivity of about 0.8 ton/h and power consumed of about $2.2 \mathrm{~kW}$.

(Mohammed and Idris, 1991; Backeit et al., 1994) reported that Soybean, Roselle seed and kenaf seed meals had similar apparent digestibility coefficient values for crude protein, and Roselle seed meal replaced peanut meal with no adverse effects on growth of broiler chicks and laying hens

(Kotb 1997). Developed and tested three equipments to separate the sepals from the Karkadi flowers after harvesting. The separation force was estimated with $90 \mathrm{~N}$. He also added that, the suitable orifice diameter range between 24 to $26 \mathrm{~mm}$, which give high separation percent and low separation strength capacity. The equipment productivity $9.25 \mathrm{~kg}$ sepals per hours. The yield of dry sepals of $300-450 \mathrm{~kg} / \mathrm{fed}$., fiber of $500-700$ $\mathrm{kg} / \mathrm{fed}$. And the oil of Karkadi was $400-500 \mathrm{~kg} / \mathrm{fed}$. The net profits in manual cultivation are estimated $460 \mathrm{LE} / \mathrm{fed}$. While the net profits in machinery cultivation had arrived $1502 \mathrm{LE} / \mathrm{fed}$., this list without the price of seeds, oils and bi-products of the yield.

Naturland and Kleinhaderner (2000) reported that harvesting commences once the calyxes have reached an optimum size. This point is generally reached shortly before the seed capsules are ready to open, 1520 days after blossoming. The fruit is separated with the calyx petals manually, either by hand, or with a knife. Afterwards, the seed capsules need to be carefully removed from the calyxes. Round, sharpened metal tubes can be used for this, to cut away the seed capsules at the base, and remove them.

Therefore, the objectives of the present research were: 
1- Developing and manufacturing appropriate machine for separation Roselle sepals.

2- Evaluating the developed machine performance under different operating parameters, and comparing it with the manual method.

\section{MATERIALS AND METHODS}

A Roselle sepal separation machine was developed and fabricated in a local shop. The experiments have been carried out at El-Kasassin Horticulture Research station Ismailia Governorate during 2011 in order to study the effect of: different cutting pipe speed, different orifices dimensions, and different span time between harvesting and sepals separation (or sepals moisture contents 82, 76 and $69 \% \mathrm{wb}$ ) on separation Roselle sepals operating performance.

A- Stationary sepal separation machine specifications

1- Steel frame fabricated from steel angles $5 \mathrm{~mm}$ thickness and $5 \times 5 \mathrm{~cm}$ with overall dimensions: 60,60 and $70 \mathrm{~cm}$ for length, width and height respectively.

2- Feeding disc is a wood disc contains 18 orifices, distributed in three rows as shown in Fig. (1).Two dimensions was used to select the suitable oriffice dimensions (19/23 and 21/25mm).The fruits is fed manually at different orifices.

3- The separation unit consists of a hollow metal pipe with serrated sharp edge turn different angular velocities in horizontal level and the separation process was done when labour press the separation wood frame Fig.(1) above the rotary serrated sharp edged of the tools, at this moment the sepals separate from its fruits. the edged tool diameter was $17 \mathrm{~mm}$ and all tools rotate by two chains around eighteen gears $68 \mathrm{~mm}$ diam. and 16 teeth translate the motion from gear box .

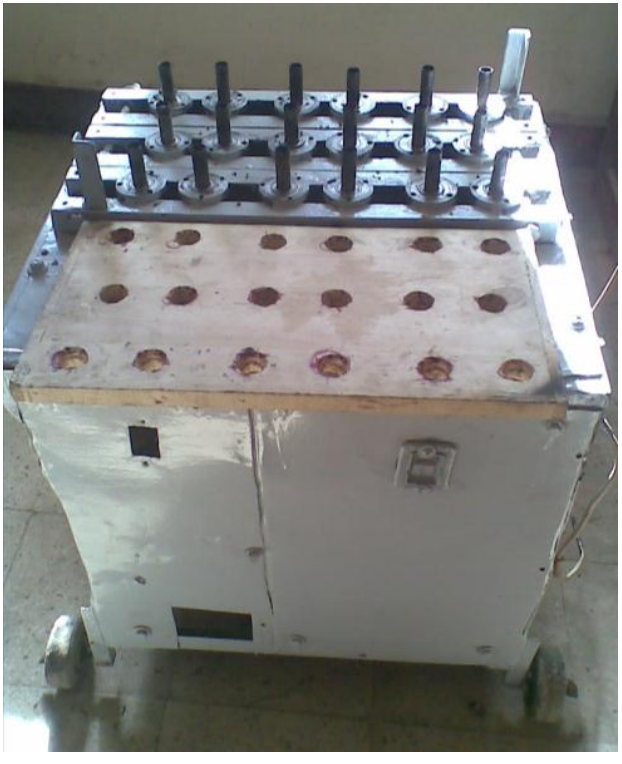

Fig (1): Photograph of the separation sepals machin. 
4-Transsimion system consists of two chains 130 and $95 \mathrm{~cm}$ transfer the motion from electric motor to 18 gears after speed reduction (16:1) under two step reduction as shown in Fig.(4) .

5- Electrical motor $1 \mathrm{hp} \mathrm{AC-}(0.75 \mathrm{~kW})$ two-phase operating at 1440 rpm.

6- Seedpods releasing unit mechanism:

After the labor raising the wood feeding disk with separation sepals, the mechanism was used to release seedpods directly. The simple mechanism consists of movable up and dawn 18 bars having $12 \mathrm{~mm}$ diameter and $22 \mathrm{~cm}$ length. The bar move internal the hollow metal pipe with slider crank mechanism which used to drives the piston up and dawn, and the piston carry a plate having 18 bars as shown in Fig.( 2 )., in our case hand labor drives the crank by raising the arm $90^{\circ}$.

\section{Separation sepals from Roselle fruits include the following steps:}

1- The fruits fed manually in wood feeding disk after harvesting.

2- The oriffice dimensions is $19 / 23$ and $21 / 25 \mathrm{~mm}$ hole diameter in top and bottom, while disk thickness having $25 \mathrm{~mm}$.

3- The labor carries the feeding disk and put it on the turning pipes to pass and penetrate the oriffice, at this moment the serrate sharp edged of pipes cut and separate sepals from its fruits while seedpods set internal turning hollow pipe .

4- A movable bar $12 \mathrm{~mm}$ diam. and $21 \mathrm{~cm}$ length moves up and dawn through turning hollow pipe which designed to releasing seedpods auto manual.

5- The separation sepals collect to dry it, while seed podes collect to dry and threshing for its seed yields. Roselle seeds might be provided as a new source of edible oil about $20 \%$ edible oil, and the residue produced after extract the oil is uses as a good feedstuff. EL-Sayed et.al. (1998) 


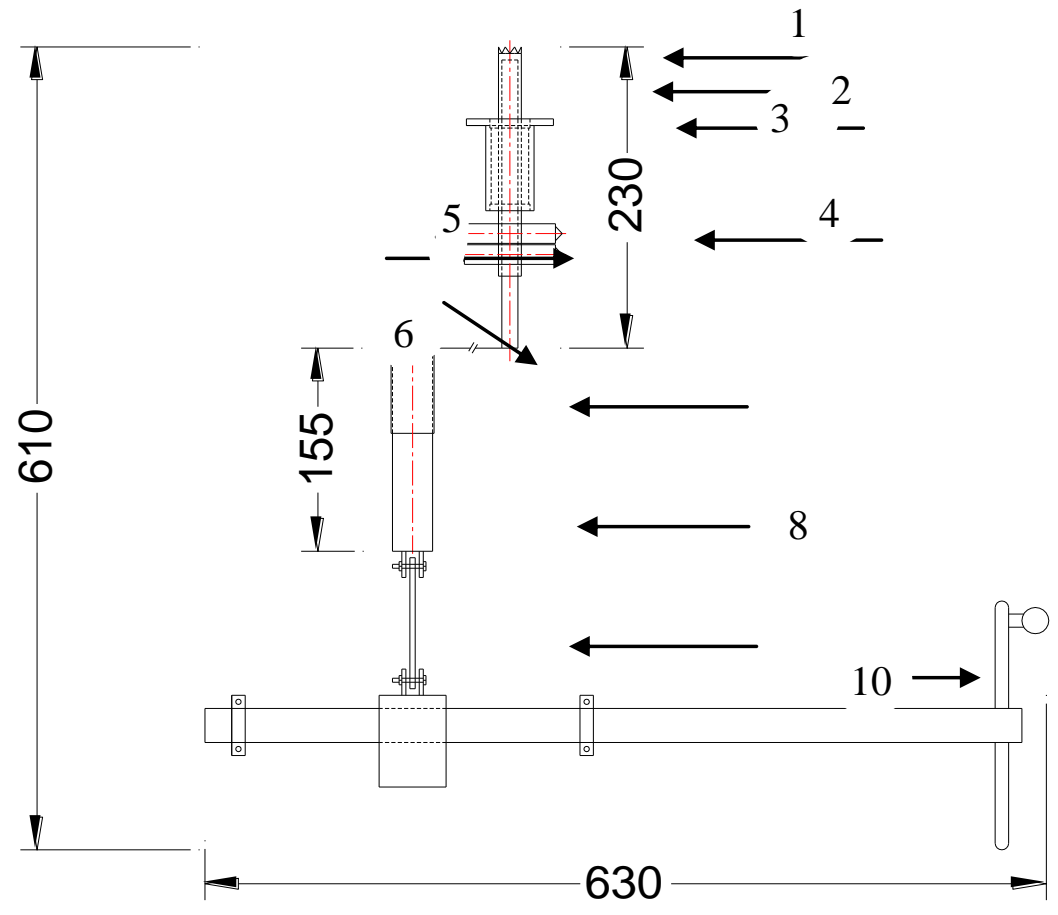

\section{ELEVATION All diam.in mm}

Fig. (2) Schematic diagram of Roselle sepals separation machine. 1-Cutting sepals pipe, 2- Piston for separation seed boll, 3- Plate, 4-First gear, 5-Second gear, 6-Movable up and down piston carrier, 7-Fixed cover, 8-Rod, 9-Crank rod mechanism, 10-Lever jac.
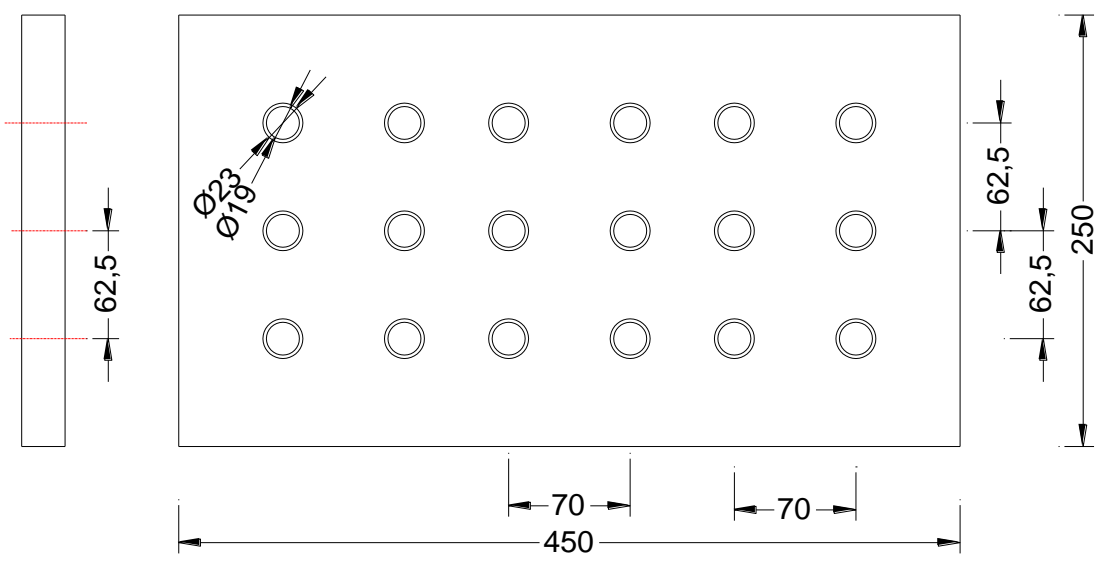

SIDE V.

PLAN V.

All diam.in mm

Fig. (3) Schematic diagram of Roselle fruits wood feeding disk. 


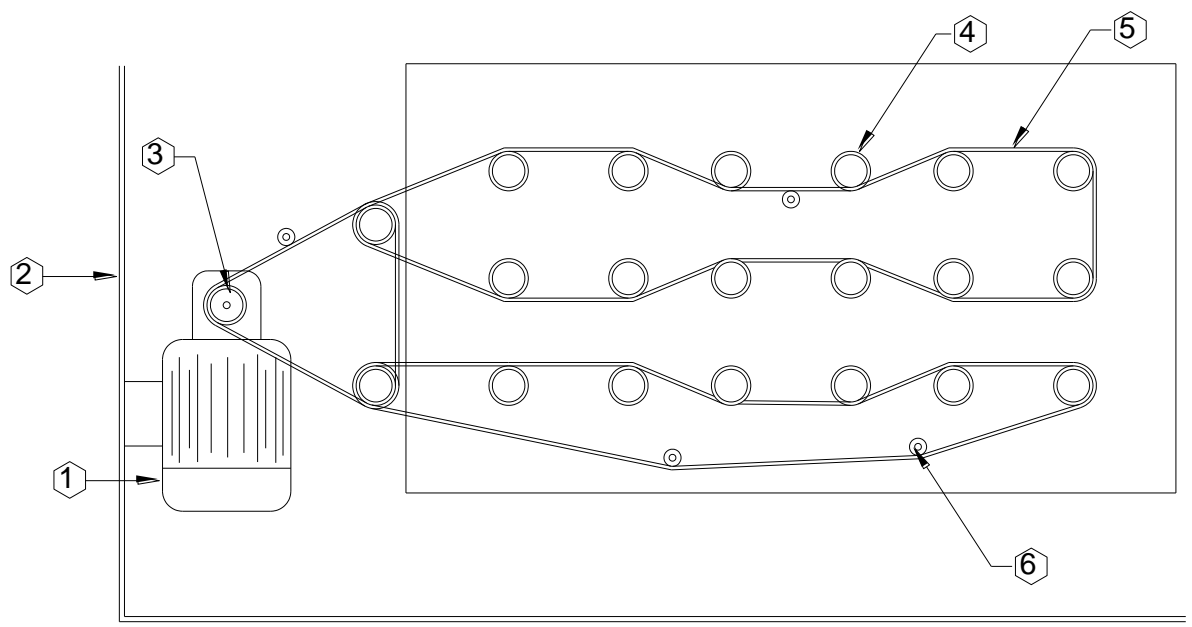

Fig. (4) Transemission system in separation sepals machine.

1- Electric motor, 2- Main frame, 3- Driver gear,

4- driven gear (16 teath), 5- Chain, 6- Pulley for pulls chain out.

The following variables were studied:

1- Three cutting sepals pipe (CSP) speed $0.047,0.094$ and $0.14 \mathrm{~m} / \mathrm{s}$ or (50, 100 and $150 \mathrm{rpm}$ respectively).

2- Different span times between harvesting and separation process directly after harvesting, second day and third day or (sepals moisture contents 82,76 and $69 \% \mathrm{wb}$ ) respictively.

3- Two oriffice dimensions $19 / 23$ and $21 / 25$ hole diameter in top and bottom in the wood feeding disc.

\section{Measurements}

\section{1- Physical properties of Roselle fruits.}

The aim of this work is to develop a separation sepals machine, thereby it is necessary know the physical properties of Roselle fruits to select the suitable feeding disk orifice dimension.

\section{2- Productivity}

The productivity of separation sepal's machine was measured as the mass of separation sepals collected per hour. During the experiments the separated sepals were collected for every 10 minutes and the productivity was calculated as follow: 


$$
\begin{aligned}
& \text { Productivity }=\frac{\mathrm{Wp}}{\mathbf{T}} \times 3.6 \mathrm{~kg} / \mathrm{hr} \\
& \text { Where Wp : sepals }(\mathrm{g}), \quad \mathrm{T}: \text { consumed time }(\mathrm{sec}) \text {. }
\end{aligned}
$$

\section{3-Determination of sepals damage:}

The criteria of the performance evaluation included sepal's damage as follow:

The percentage of damage sepals $\left(\mathbf{M}_{\mathbf{d}}\right)$ during fixing Roselle fruits in its orifices was calculated using the following formula:

\section{Md}

$$
\text { Sepals damage }(\%)=\frac{}{\text { Mt }} \mathbf{X 1 0 0}
$$

Where $\mathrm{M}_{\mathrm{t}}$ : is the total mass of sepals contained in fruits sample, $(\mathrm{g})$.

\section{4-Machine separating efficiency \%}

The efficiency of the machine in sepal separation was calculated according to the following equation:

$\mathrm{Mc}$

Separating efficiency $\%=\longrightarrow \times 100$

$$
\mathbf{M}_{\mathbf{t}}
$$

$\mathrm{M}_{\mathrm{c}}$ : mass of collected properly coherent sepals, $(\mathrm{g})$.

\section{5-Total consumed power}

The separation power consumed was calculated from the knowledge of electric line current strength (I) and potential difference values (V) using the following Formula:

Total consumed power $(\mathbf{k W})=I V \eta \cos \theta / 1000$

\section{Where:}

I: Line current strength in amperes.

$\mathbf{V}:$ is the Voltage ( being equal to 220volt).

Cost: Power factor (being equal to 0.85)

$\boldsymbol{\eta}$ : Mechanical efficiency assumed (90\%).

\section{6- Specific consumed energy}

The separating machine specific energy requirement for Roselle sepals was calculated as follow: 
Total consumed power $(\mathrm{kW})$

Specific energy requirement $(\mathrm{kW} \cdot \mathrm{h} / \mathrm{kg})=$

Machine productivity $(\mathrm{kg} / \mathrm{h})$.

7-Operating cost:

The total cost for separation Roselle sepals per hour was estimated according to the conventional method of estimating both fixed and variable costs. While the cost per mass unit was calculated using the following equation:

\section{Total cost (L.E / h) \\ Cost per mass unit of sepals $(\mathrm{L} . \mathrm{E} / \mathrm{kg})=$ \\ Productivity (kg/h)}

\section{RESULTS AND DISCUTION}

\section{1- Physical properties of Roselle fruits}

Fig. (5) indicates that the flower length, diameter and neck diameter ranges of sample were $27-55 \mathrm{~mm}$ (average $36.76 \mathrm{~mm}$ ), $22-36 \mathrm{~mm}$ (average $30.02 \mathrm{~mm}$ ) and $4.9-7.5 \mathrm{~mm}$ (average $6.04 \mathrm{~mm}$ ) respectively. The most frequent percent $(92 \%)$ of flower in the sample have $35-45$ mm length, (88\%) of flower in the sample have $30-35 \mathrm{~mm}$ diameter and (76\%) of flower in the sample have 6-6.5 mm neck diameter

\section{2-Effect of some different operating parameters on machine productivity:}

The effect of deferent levels of cutting sepals pipe(CSP) speed ,different span time between fruits harvesting and separation process and using wood feeding disk with two orifices dimensions on machine productivity is shown in Fig.(6). The increase of machine productivity by increasing CPS speed could be due decreasing contact time between fruits and pipes with serrated sharp edge, at the same time the productivity increase when sepals separate after harvesting directly (zero time) due to increasing moisture content in sepals and lowest cutting resistant and contact time. There are a relation between oriffice dimension of feeding disk and manual feeding time causing to different levels of size fruits, 

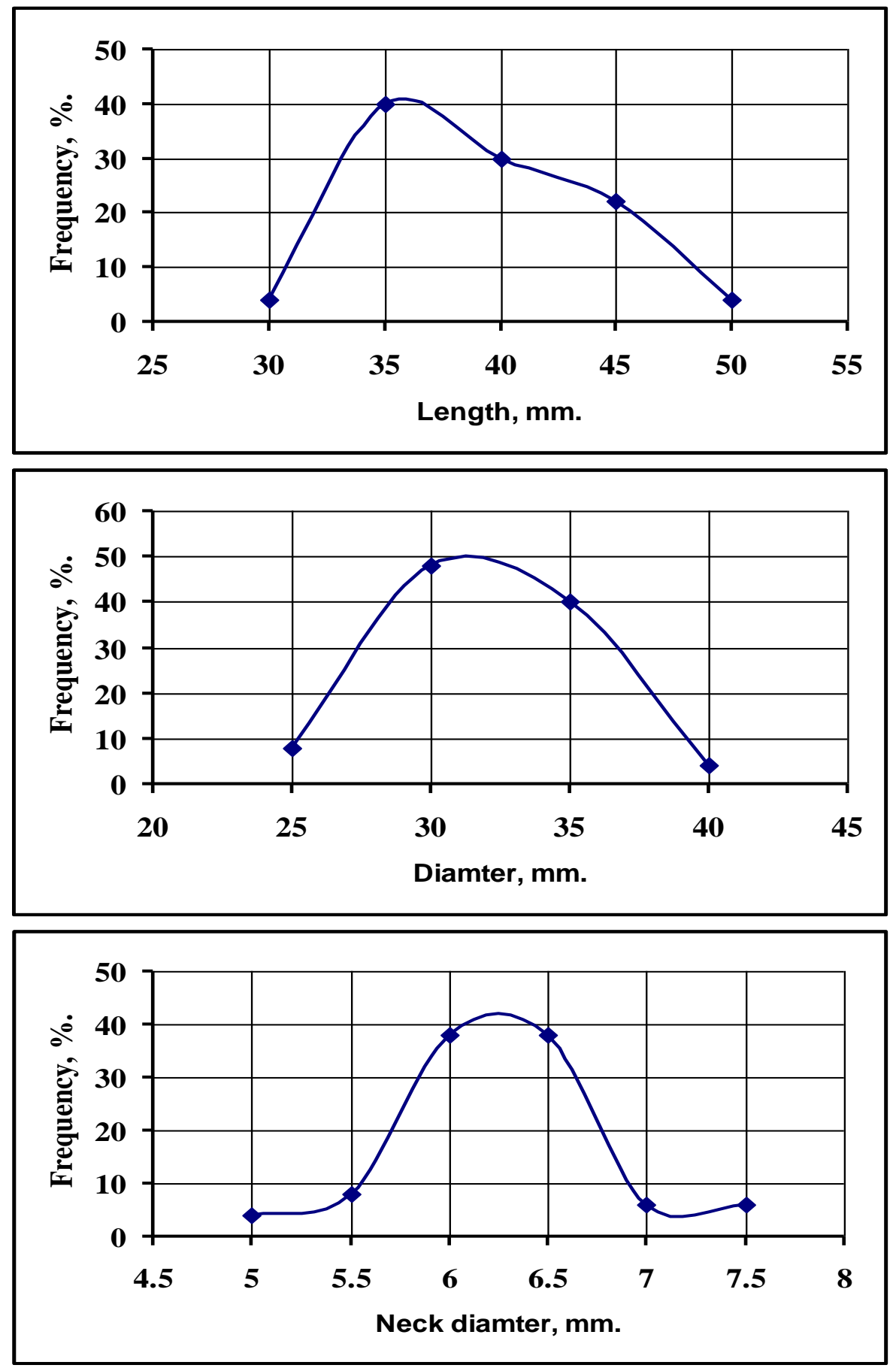

Fig. 5: Frequency of flower length, diameter and neck diameter. 
it is noticed that the feeding time decreased when using wood feeding disk having oriffice with $21 / 25 \mathrm{~mm}$ dimension this lead to increas machine productivity. The highest value of machine productivity of $18.5 \mathrm{~kg} / \mathrm{h}$ was obtained at CPS of $150 \mathrm{rpm}(0.14 \mathrm{~m} / \mathrm{s})$, and separation process using fleshy fruits after harvesting directly and using wood feeding disk with oriffice $21 / 25 \mathrm{~mm}$ dimension.

There is different variation between sizes Roselle fruits, most of sepals damage were done during fixed it in its orifices. There are many

parameters which were affected in sepals damage ratio such as span time after harvesting or late of separation process, oriffice dimension

and, cutting sepals pipe (CSP) speed . The late span time lead to decrease moisture content in the sepals and increase cutting resistance and time contact, change in its dimensions, all these defects reduce the marketing values of fruits. Fig. ( 7 )shows the relation between each of cutting sepals pipe(CSP) speed and different span time of separation under two oriffice dimensions19/23 and 21/25 hole diameter on seed damage, the percentage of damage sepals was inversely proportional to hole diameter and late of separation after harvesting. The minimum

percentage of sepal's damage $1.56 \%$ was recorded under $50 \mathrm{rpm}$ and using oriffice having 21/25 hole diameter and separation after harvesting directly.

\section{4- Effect of some different operating parameters on sepals separation efficiency.}

Separation sepal's efficiency is an important indicator to the percentage of the coming out product. The manual separation led to cutting fruit sepal to many pieces, after during and during packaging breaks up into small pieces and less value to marketing. While, in mechanical separation the coming out product as a coherent sepals resembling Lotus flower as standards for export, and thus the farmer get highest price. It can be observed from Fig. ( 8 ) that the maximum value of sepals separation efficiency $(98.36 \%$ ) was obtained at a $100 \mathrm{rpm}$ cutting sepals pipe(CSP) 
speed, separation process using fleshy fruits after harvesting directly and using wood feeding disk with oriffice $21 / 25 \mathrm{~mm}$ dimension.

- The sepals separation efficiency decreased with increased span time even two days by increasing cutting resistant, the oriffice dimension was affect on separation efficiency, however the minimum value $(92.22 \%)$ was recorded at a cutting sepals pipe(CSP) speed $150 \mathrm{rpm}$, separation process after two days from harvesting and using feeding disk with 19/23 oriffice dimension.

\section{5- Effect of some different operating parameters on Specific consumed energy.}

The separation sepal's energy requirements depend theoretically on consumed power and machine productivity, but practically on effect of different operation parameters. The relation between the cutting sepals pipe speed (CSP) and specific energy consumption (SEC) $(\mathrm{kW} \cdot \mathrm{h} / \mathrm{kg})$ of different separation span time after harvesting at different orifices dimensions is shown in Fig.(9) Data shows that increasing pipes cutting speed from 50 to $150 \mathrm{rpm}$ decreased the percentage of energy requirement from 0.059 to $0.049,0.067$ to $0.062,0.083$ to 0.077 at oriffice $19 / 23$ $\mathrm{mm}$ and from 0.053 to $0.044,0.062$ to 0.058 and 0.077 to $0.075 \mathrm{~kW} . \mathrm{h} / \mathrm{kg}$ at orifice $21 / 25 \mathrm{~mm}$ under different (CSP) and consequently decreased sepals moisture content from 82 to $69 \%$, as a result of increasing cutting sepals resistance..

\section{6- Effect of some different operating parameters on cost analysis:}

A detailed cost analysis of different elements included in the extracting processing was carried out in order to evaluate the economical feasibility of separation Roselle sepal's machine. In this study some parameters were calculated as the absolute total including both fixed and variable costs per hour according to (ASAE, 1980) and price level of 2011.

Table (1): The calculation cost for separation Roselle sepals machine machine comparing to manual method.

\begin{tabular}{|l|c|c|}
\hline \multicolumn{1}{|c|}{ Item of cost analysis } & $\begin{array}{c}\text { Separation Roselle } \\
\text { Sepals machine }\end{array}$ & $\begin{array}{c}\text { Manual } \\
\text { separation }\end{array}$ \\
\hline Total hourly fixed cost, L.E/h. & 1.89 & \\
\hline Total variable costs, L.E/h & 18.63 & \\
\hline Total operation costs L.E/h & 20.52 & \\
\hline Total operation costs L.E/kg & 1.10 & $\mathbf{1 . 3 6}$ \\
\hline
\end{tabular}


These costs were estimated at the best operating conditions for using separation machine at cutting sepals pipe (CSP) speed $0.094 \mathrm{~m} / \mathrm{s}(100$ $\mathrm{rpm}$ ) using fleshy fruits after harvesting directly $82 \%$ moisture contet and using feeding disk with $21 / 25 \mathrm{~mm}$ orifice diameter.

The total operation cost $1.10 \mathrm{~L} . \mathrm{E} / \mathrm{kg}$ and $1.36 \mathrm{~L} . \mathrm{E} / \mathrm{kg}$ in mechanical and manual separation sepals respectively, shortage of laborers reduce the horizontal expansion in Roselle cultivation.

Crop Value $(\mathrm{LE} / \mathrm{fed})=$ crop prod. $(\mathrm{kg} /$ fed. $) *$ Crop sale value $(\mathrm{LE} / \mathrm{kg})$.

There are high variation in product qualityin manual and mechanical method and thus in its sale. There are additional benefits from Roselle seeds utilization as a source of oil ranged from $15.31 \%$ to $18.99 \%$, the residue produced after extract the oil is uses as feedstuff for animals.

According to the obtained data it is obvious that, the cost of the separation sepals increased when feeding at orifice 19/21 diameter, using fruits after two days from harvesting and 50rpm for cutting sepals pipe (CSP) speed. The previous parameters lead to decrease a machine productivity that is meaning a high increase of operating cost.

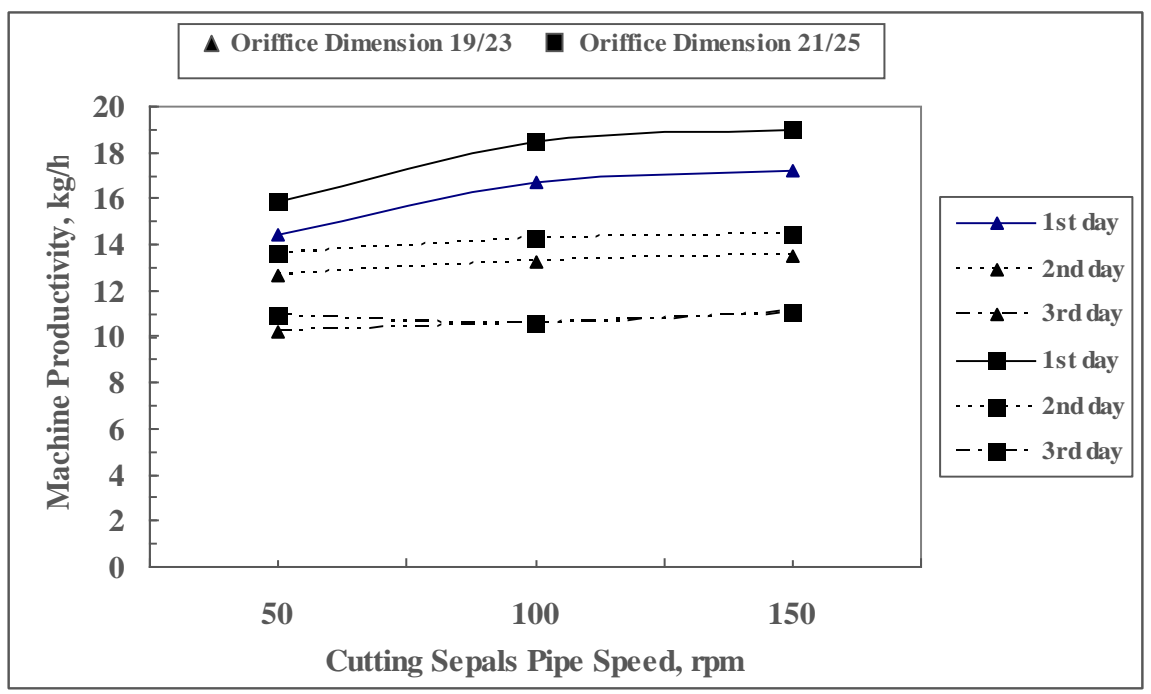

Fig.(6) 3- Effect of some different operating parameters on machine productivity. 


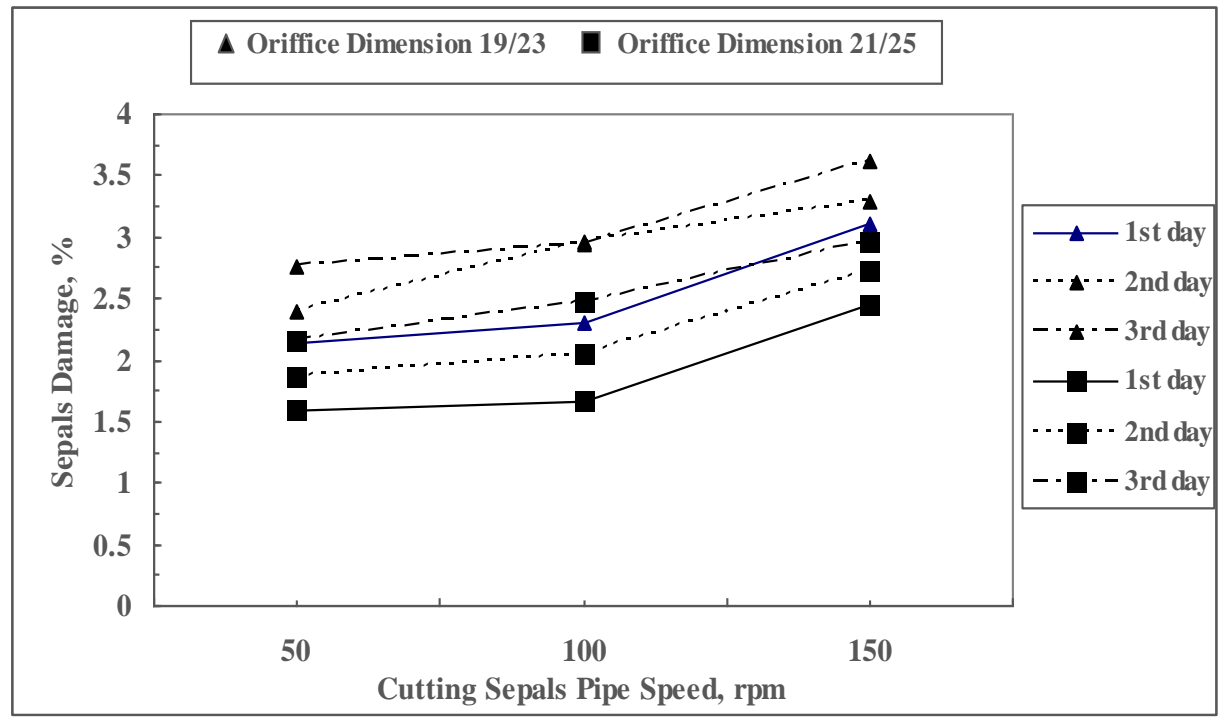

Fig.(7)- Effect of some different operating parameters on sepals damage.

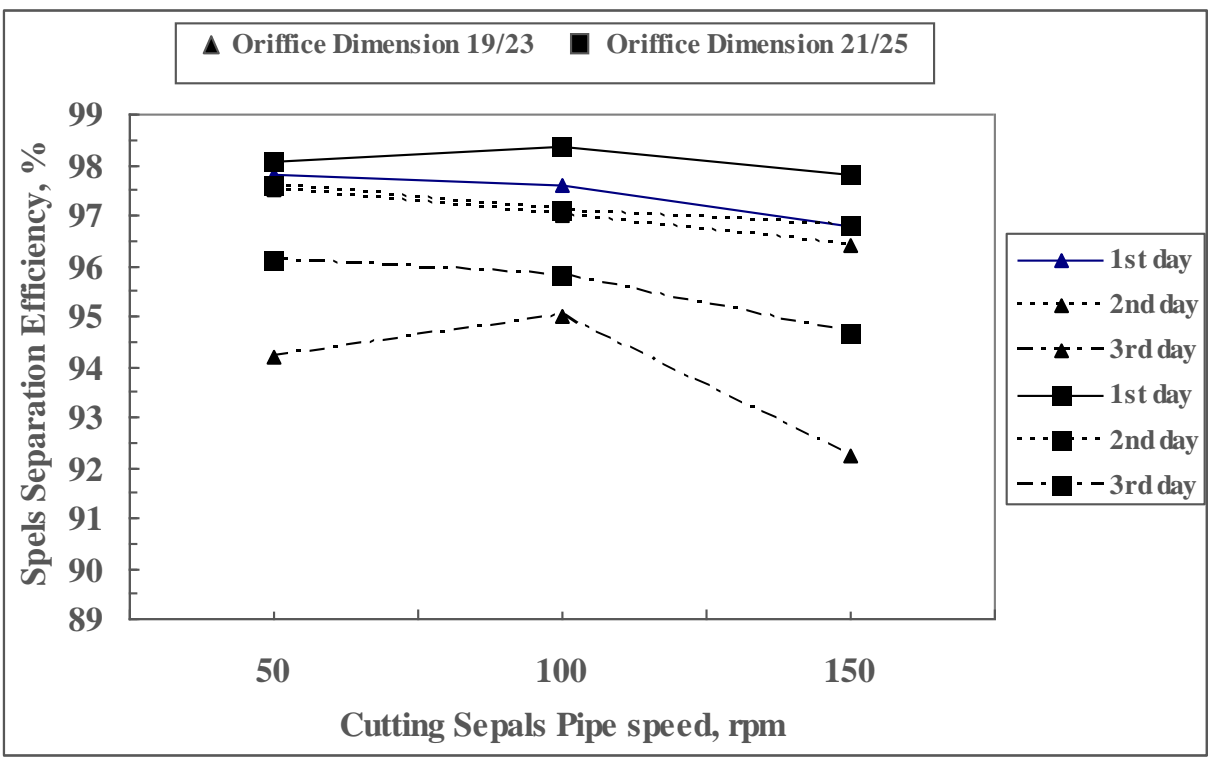

Fig.(8)- Effect of some different operating parameters on separation efficiency. 


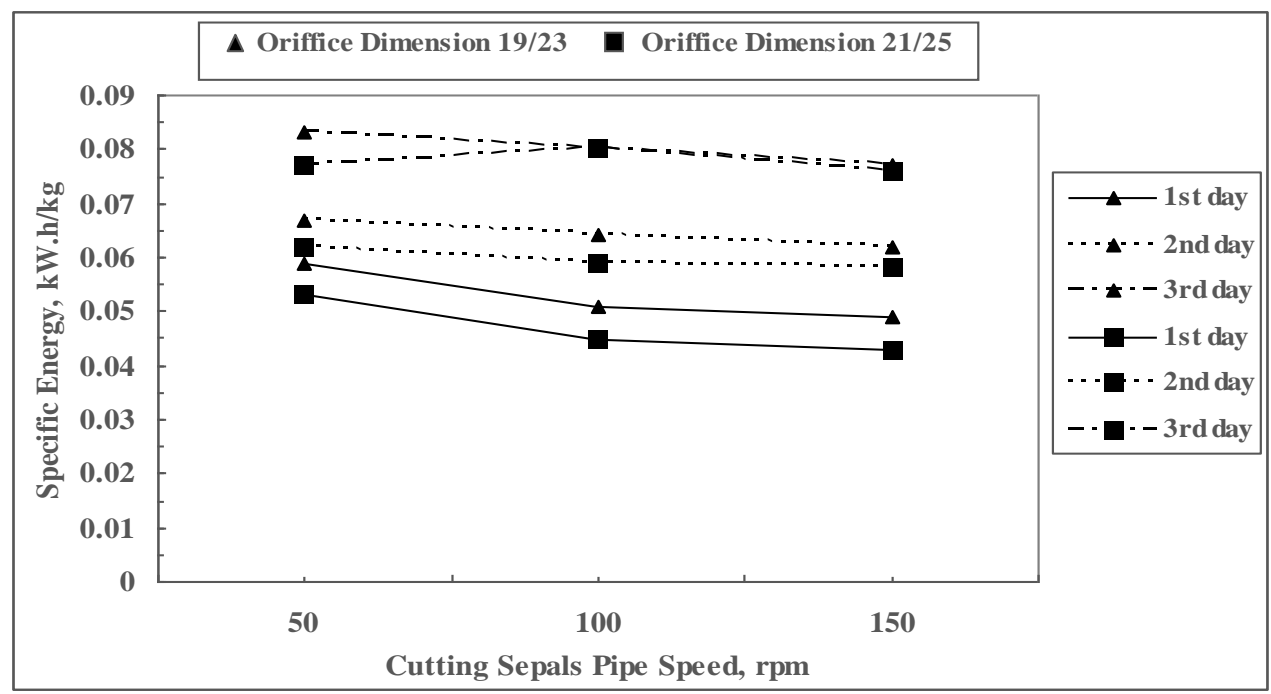

\section{Fig (9): Effect of the operation parameters on Specific Consumed Energy}

\section{CONCLUSIONS}

The main objective of the present investigation is to develop a low cost Roselle sepals separation machine; it was locally designed and manufactured. In addition, the performance of the developed machine was evaluated based on machine productivity, sepal damage, separation efficiency, consumed specific energy and separation cost analysis. The evaluation was conducted at three cutting sepals pipe(CSP) speed 0.047, 0.094 and $0.14 \mathrm{~m} / \mathrm{s}(50,100$ and $150 \mathrm{rpm}$ respectively), different span times between harvesting and separation process directly after harvesting, second day and third day ( 82,76 and $69 \%$ m.c respictively) and two oriffice dimensions19/23 and 21/25 hole diameter in top and bottom in the wood feeding disc. It is recommended to operate the Roselle sepal separation machine with CSP of $100 \mathrm{rpm}$, separation process directly after harvesting and using feeding with orifice 21/25 hole dimensions to achieve the highest values of machine productivity of $18.522 \mathrm{~kg} / \mathrm{h}$, separation efficiency $98.36 \%$ and lowest sepal damage of $1.66 \%$ and specific energy of $0.045 \mathrm{~kW} . \mathrm{h} / \mathrm{kg}$. Total operation costs was 1.10 and $1.36 \mathrm{~L} . \mathrm{E} / \mathrm{kg}$ in mechanical and manual separation method respectively, but while the net crop value from final product of sepals is much more expensive in mechanical method comparing to traditional manual method. 
It can be recommended to continuing research about best Roselle separation sepal mechanization to get higher efficiency and lower cost.

\section{REFERENSEC}

Backeit, M.H., El Zubeir, E.A. and Jubarah, S.K. (1994). "The nutritional value of Roselle seed meal in laying hen diets". Journal of Science of Food and Agriculture 65: 199-200.

Badr, S.E.; E. Mousa and N.K. Ismail (2005) The engineering factors affected the Karkadea threshing. The $13^{\text {th }}$ Conference of the Misr Society of Agr. Eng., 14-15 December, 2005: 887- 896.

Diatta M. and E.S. James (2007). Quality assessment of hibiscus (Hibiscus Sabdariffa) calyces from senegal. AAIC Annual Meeting: Bringing Industrial Crops into the Future October 7-10. Portland, Maine. The State University of New Jersey, 59 Dudley Rd, New Brunswick, NJ 08901-8520, USA.

Duke, J.A. (1978). The quest for tolerant germplasm. In: Crop tolerance to suboptimal land conditions. Madison: American Society of Agronomy, 1978. p. 1-61.

El-Sayed, H., S.T. Kheir, and M.B. Atta, (1998). Some physico-chemical characteristics and fatty acid composition of roselle (Hibiscus sabdariffa L.) seed oil. Assuit J. Agric. Sci., 29: 103-113..

Kotb, F.E. (1997). Equipment design for separation of hibiscus fruit petals and its drying. Ph D, Thesis, Agricultural Mechanization Dept. Ain Shams University.

Mohammed, T.A. and Idris, A.A. 1991. "Nutritive value of roselle seed (Hibiscus sabdariffa) meal for broiler chicks". World Review of Animal Production XXVI. pp. 59-62.

Muller, B.M. and G. Franz, (1992). Chemical structure and biological activity of polysaccarides from Hibiscus sabdariffa. Planta Medica., 58: 60-67.

Naturland, E.V. and W. Kleinhaderner (2000). Organic Farming in the Tropics and Subtropics Exemplary Description of 20 Crops Hibiscus. Naturland E.V. $-1^{\text {st }}$ ed. Germany.

Sharaf, A., (1962). The pharmacological characteristics of Hibiscus sabdariffa L. Planta Medica, 10: 48-52.

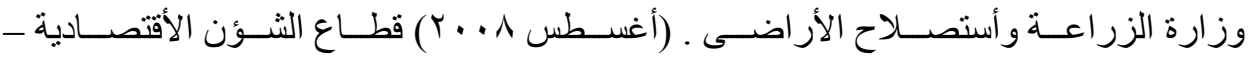
الإحصاءات الزراعيةـ المحاصيل الصيفية و النيلية ـ صفحة 292. 
وز ارة التجارة الخارجية قطاع بحوث التسويق والدر اسات السلعية و المعلومـات ه ـ . ب م ( رؤيسة حول تتمية صادر ات مصر من النباتات الطبية و العطرية ومحددات التنافسية الدولية).

\section{الملخص العربي \\ تطوير آلة لفصل سبلات الكركدية}

\section{د عاطف احمد عليوة}

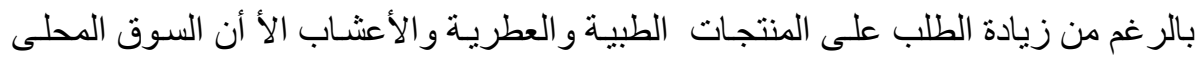

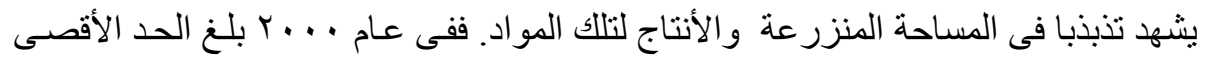

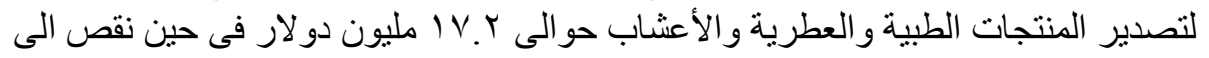

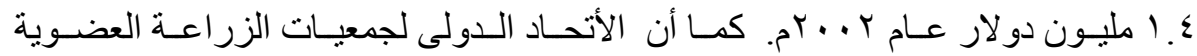

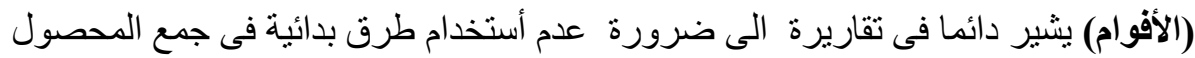

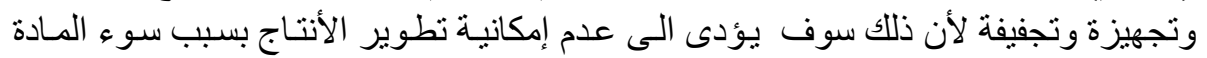
الخام المنتجة. نبات الكركديةHibiscus Sabdariffa أحد هذة النباتات الطبيـة و العطريـة

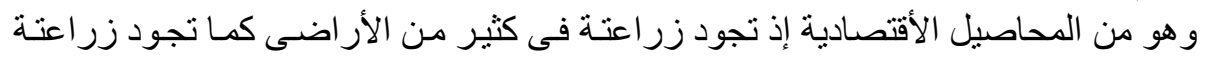

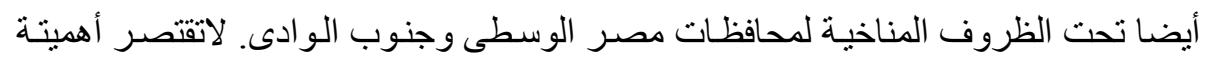

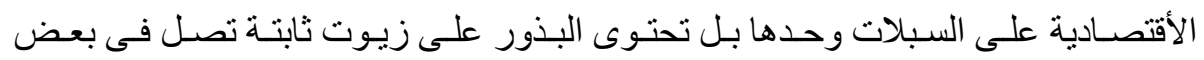

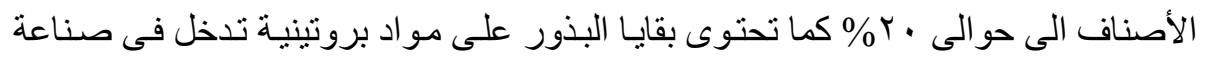

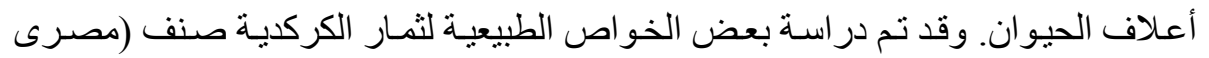

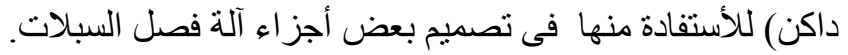

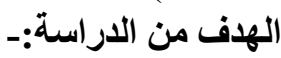

ا ـ تطـوير آلـة لفصـل سـبلات الكركديـة متماسـكة السـبلات تشـبة زهـرة اللـوتس طبقـا

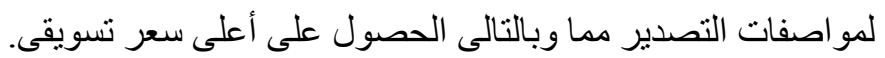
r- أختيار أنسب ظروف تشغيل لألة الفصل. حساب التكاليف مقارنة بالطريقة اليدوية المتبعة.

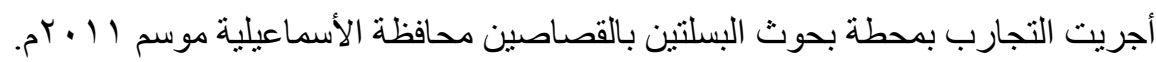
تثم عملية فصل السبلات في الخطوات التبالية:-

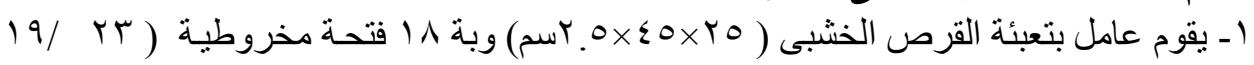

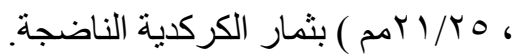

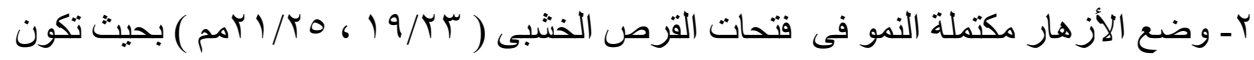

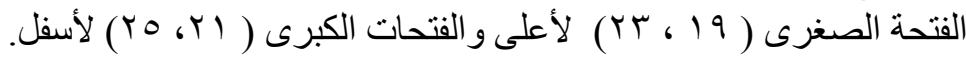

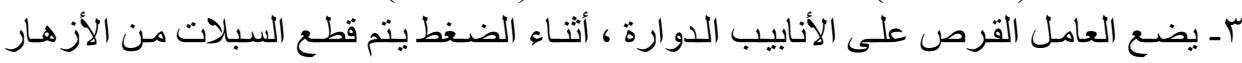

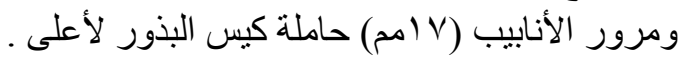

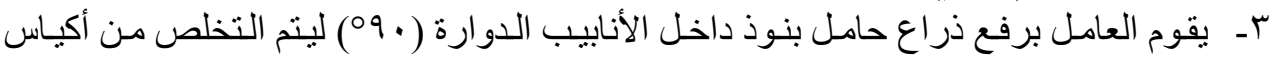
البذور وجمعها بعيدا عن السبلات.

* باحث أول بمعهد بحوث الهندسة الزراعيةـ مركز البحوث الزراعيةـ الدقى ـمصر. 
عـ ـ يقوم العامل بعد ذلك بتفريخ القرص الخثبى بمـا فيـة من سبلات في صندوق جمع

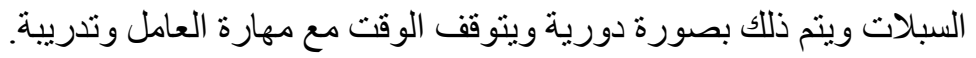

هذا وقد تم دراسة المتغيرات الأتية:

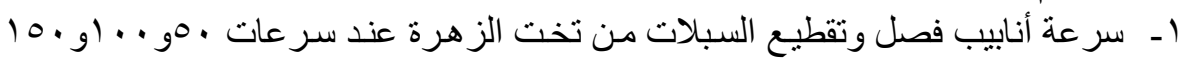

لفة/دقيقة.

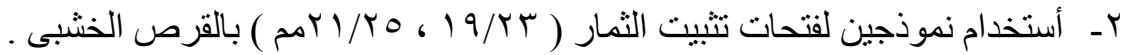

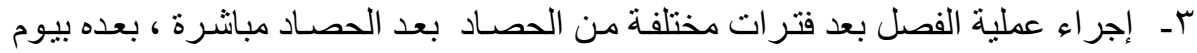

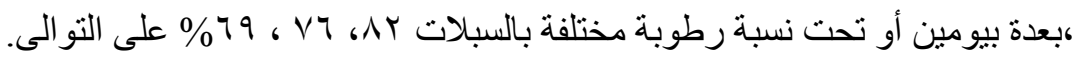

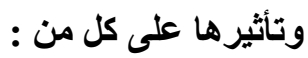

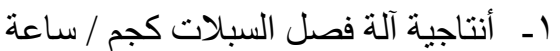

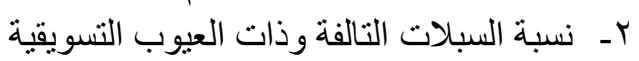

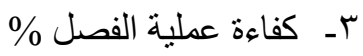
عـ - مالطاقة المستهلكة 0ـ ـكاليف التشغيل مقارنة بالطريقة البدوية الثائعة وقد تم التوصل للتتائج التالية:-

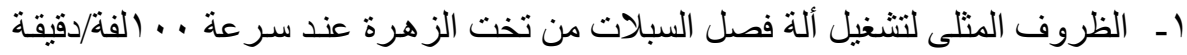

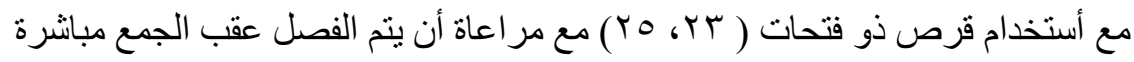
تحت نسبة بر \% للسبلات.

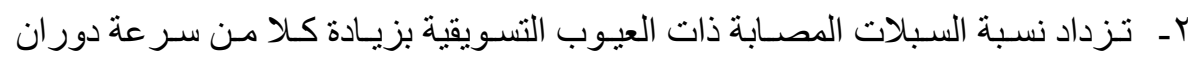

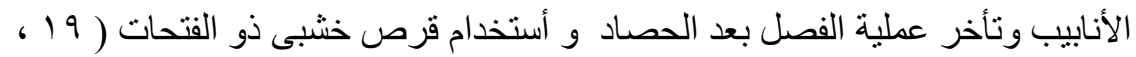

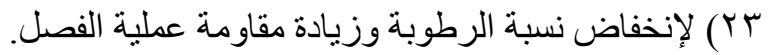

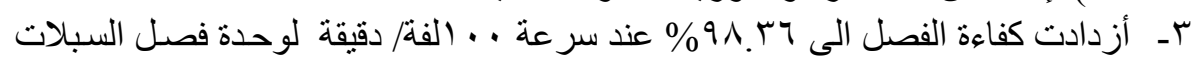

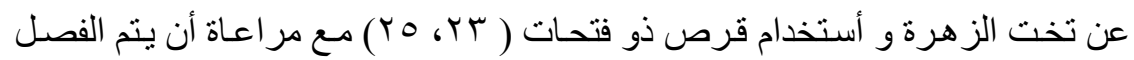
عقب الجمع مباشرة.

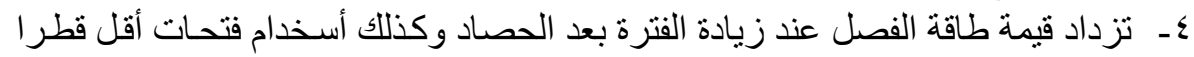

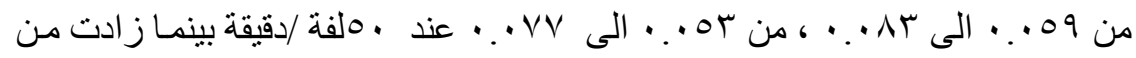

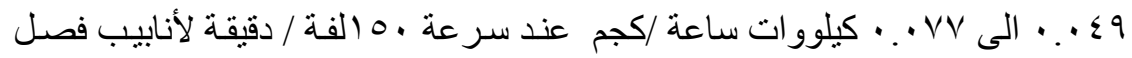

$$
\text { السبلات. }
$$

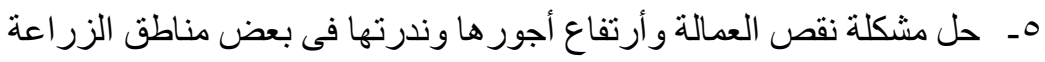

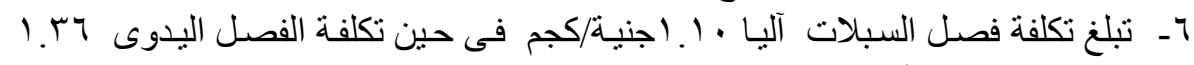

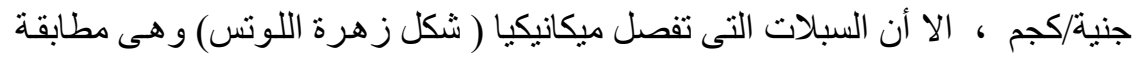

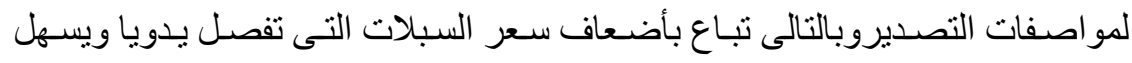
تصدير ها.

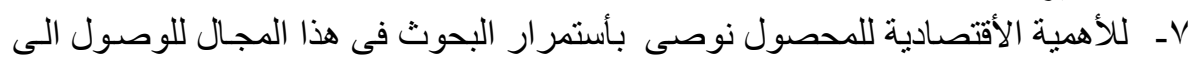
آلية تحقق أعلى كفاءة فصل و أكثر أنتاجية و أقل تكلفة. 